\title{
Promosi Cyber Film Bumi Manusia
}

\author{
Safa, Eko Harry Susanto \\ Safa.915160129@stu.untar.ac.id,Ekos@fikom.untar.ac.id
}

Fakultas Ilmu Komunikasi Universitas Tarumanagara

\begin{abstract}
Promotion in the cyber world today, if it is connected with the film industry becomes an interesting aspect to be understood and researched as part of advertising communication activities. One of the local films that successfully attracted the attention of the audience, and the author to do research is the Earth Human Film adapted from the novel titled the same as the film by the leading Indonesian literary writer, the well-known controversy, namely Pramoedya Ananta Toer. How did the promotion of cyber film human earth produced by Frederica from Falcon Pictures Production House succeeded in gaining an audience of 1,296,714 people in less than 1 (one) month since its initial airing released. This study uses the promotion mix theory (promotional mix) by G. Belch and M. Belch, with 6 basic elements namely advertising, direct marketing, internet marketing, sales promotion, publication, and personal selling. The results showed the dominant Falcon Pictures using internet marketing, advertising and publications, and chose not to use personal selling to promote human earth films. Suggestion The writer needs to explore the application to increase the number of movie sales and improvise the film's storyline to expand the audience segmentation.
\end{abstract}

Keywords: promotion, cyber promotion, film

\begin{abstract}
Abstrak
Promosi di dunia cyber saat ini, jika dihubungkan dengan industri perfilman menjadi satu aspek yang menarik untuk dimengerti dan diteliti sebagai bagian dari aktivitas komunikasi periklanan. Salah satu film lokal yang sukses menarik perhatian audiens dan Penulis untuk melakukan penelitian adalah Film Bumi Manusia yang diadaptasi dari Novel berjudul sama dengan filmnya, hasil karya sastrawan terkemuka Indonesia yang terkenal sekaligus kontroversial yaitu Pramoedya Ananta Toer. Dengan menggunakan metode kualitatif, Peneliti menguraikan bagaimana Promosi Cyber Film Bumi Manusia yang diproduseri oleh Frederica dari Rumah Produksi Falcon Pictures ini berhasil mendapatkan perolehan penonton sebesar 1.296 .714 orang dalam waktu kurang dari 1 (satu) bulan sejak rilis tayang perdana. Penelitian ini menggunakan teori bauran promosi (promotional mix) oleh G. Belch dan M. Belch, dengan 6 elemen dasar yaitu iklan, direct marketing, internet marketing, promosi penjualan, publikasi, dan personal selling. Hasil penelitian menunjukkan Falcon Pictures dominan menggunakan internet marketing, beriklan dan publikasi, serta memilih untuk tidak menggunakan personal selling untuk promosi Film Bumi Manusia. Saran Penulis perlu adanya eksplorasi publikasi untuk menaikkan angka penjualan film dan improvisasi alur cerita film guna memperluas segmentasi penonton.
\end{abstract}

Kata Kunci: film, cyber promotion, promosi 


\section{Pendahuluan}

Penyampaian pesan dan informasi saat ini dirasakan mengalami perkembangan luar biasa sebab kemajuan teknologi komunikasi dan media informasi. Kemajuan perangkat teknologi dan komunikasi mampu memberikan budaya baru yang terjadi dan tengah berkembang di masyarakat. Terutama dalam proses komunikasi dan distribusi pesan melalui keterwakilan (interface), sebagaimana karakteristik dari internet dan dunia maya (cyber).

Dunia maya (cyber) telah menjadi sarana yang sangat menarik minat untuk dijadikan pasar potensial dalam periklanan saat ini. Periklanan dibutuhkan masyarakat untuk mengetahui produk ataupun bentuk layanan yang disediakan oleh penyedia barang dan jasa yang dipasarkan, sehingga memudahkan masyarakat untuk menggunakan ataupun mengakses layanan dimaksud. Menurut Rambat Lupiyoadi (2006:120) kegiatan promosi bukan saja berfungsi sebagai alat komunikasi antara perusahaan dengan konsumen, melainkan juga sebagai alat untuk mempengaruhi konsumen dalam kegiatan pembelian atau penggunaan jasa sesuai dengan keinginan dan kebutuhannya.

Promosi di dunia cyber saat ini, jika dihubungkan dengan industri perfilman menjadi satu aspek yang menarik untuk dimengerti dan diteliti sebagai bagian dari aktivitas komunikasi periklanan. Perkembangan industri perfilman saat ini dinilai baik dan potensial, serta mampu menarik perhatian khalayak ramai. Di Indonesia sendiri, perkembangan perfilman telah menunjukkan kemajuan yang cukup pesat. Tak sedikit masyarakat Indonesia yang menaruh perhatian dan minat atas film-film lokal yang tayang di bioskop Indonesia. Salah satu film lokal yang sukses menarik perhatian audiens adalah Film Bumi Manusia yang diadaptasi dari Novel berjudul sama dengan filmnya hasil karya Pramoedya Ananta Toer.

Pramoedya Ananta Toer atau yang akrab disapa Pram adalah seorang sastrawan terkemuka Indonesia, yang terkenal sekaligus kontrovesial karena pernah dijebloskan ke Penjara Salemba sampai ke Penjara Tangerang pada Zaman Orde Baru sebab ideologi sastranya. Pram banyak menuangkan buah pikirannya mengenai ide pluralisme, konsep berdemokrasi dan feminisme menjadi karya tulis fiksi maupun non fiksi. Pram dalam karya tulisnya selalu berciri khas dengan tulisannya yang bertendensi atas nilai-nilai humanis dan realitas sosial, menguraikan jejak sejarah, hingga mengangkat biografi tokoh. Eksistensinya dalam berkarya tulis membuatnya beberapa kali dinominasikan atas penghargaan, bidang sastra baik nasional maupun internasional hingga dinominasikan sebagai penerima penghargaan Nobel.

Film Bumi Manusia yang diproduseri oleh Frederica dari Rumah Produksi Falcon Pictures ini, berhasil mendapat perolehan penonton sebesar 1.296.714 orang dalam waktu kurang dari 1 (satu) bulan sejak rilis tayang perdana Tanggal 15 Agustus 2019 di 70 (Tujuh Puluh) bioskop yang tersebar di seluruh Indonesia (dikutip http://filmindonesia.or.id/viewer\#.XXdelCUXWEc, diakses pada Hari Senin Tanggal 10 September 2019, Waktu 15.43 WIB). Falcon Pictures melakukan promosi film di media elektronik baik TV dan Radio. Promosi film yang diproduksi di Desa Wisata Studio Gamplong Kabupaten Sleman ini, juga dengan promosi cyber di berbagai media sosial online baik Facebook, Twitter, dan Instagram. Estimasi 
biaya produksi hingga pasca produksi Film Bumi manusia oleh Falcon Pictures

kurang lebih sebesar 50 miliar Rupiah (dikutip dari http://www.google.co.id/amp/s/entertainment.uzone.id/amp/-falcon-habiskan-rp50miliar-produksi-film-bumi-manusia, diunggah pada 5 Agustus 2019 dan diakses pada Hari Senin Tanggal 10 September 2019 Pukul 16.17 WIB), dan berhasil bertengger di posisi ke tujuh dari 15 film teratas Indonesia pada Tahun 2019. Hal itu bertujuan memperkenalkan kepada khalayak ramai akan produksi film yang dibintangi oleh Iqbal Ramadhan dan Mawar De Jongh ini. Melalui asumsi harga jual tiket nonton sebesar Rp. 40.000 dan jumlah Penonton sebanyak 1.296.714 orang, maka dapat dihitung jumlah laba kotor atas produksi film Bumi Manusia yakni Rp. 51.868.560.000,- dengan estimasi yang masih akan terus bertambah.

Dari fenomena yang terjadi diatas, diketahui bahwa industri perfilman Indonesia sudah mengalami kemajuan dalam beberapa dekade ini. Meskipun tidak dapat ditampik bahwa film barat selalu menawarkan cerita menarik dan masih mendominasi minat nonton audiens, namun film layar lebar Indonesia tetap memiliki porsi tersendiri bagi penggemarnya. Dominasi cerita menarik yang diangkat menjadi film layar lebar Indonesia saat ini masih film horor hantu Indonesia yang disusul oleh film berkisah romantisme remaja, komedi, dan drama dalam menarik minat pasar audiens, disusul dengan film bertemakan sejarah Indonesia. Meskipun demikian, film Bumi Manusia, menggabungkan keseluruhan cerita dari romantisme, mengulik sejarah masa lalu, dengan alur cerita yang kontroversial dari seorang sastrawan terkemuka Indonesia berdurasi 181 menit. Dengan diperankan oleh 2 aktor yang memiliki pamor gemilang saat ini, film bumi manusia dianggap Penulis menjadi cerita kompleks yang disederhanakan namun kaya akan pesan sosial. Dari hal diatas, Penulis akan melakukan penelitian terkait strategi promosi Film Bumi Manusia dalam upaya menarik minat audiens terhadap keputusan khalayak sebagai penonton.

Dalam jurnal ini Penulis melakukan penelitian untuk menganalisis promosi cyber Film Bumi Manusia, menginterpretasikan dan memahami pola komunikasi dalam promosi cyber yang baik dan efektif, serta lebih optimal dalam rangka pencapaian tujuan pelaksanaan promosi periklanan khususnya promosi cyber dalam Film Bumi Manusia. Penelitian ini dapat menjadi rujukan bagi rumah-rumah produksi untuk melakukan evaluasi kegiatan promosi maupun improvisasi ide kreatif guna peningkatan kinerja perusahaan rumah produksi.

\section{Metode Penelitian}

Dalam penelitian ini penulis menggunakan pendekatan kualitatif. Sugiyono (2011) menyatakan bahwa metode kualitatif adalah "metode yang berdasarkan pada filsafat postpositivisme, sedangkan untuk meneliti pada objek alamiah, dimana peneliti adalah sebagai instrumen kunci, teknik pengumpulan data dilakukan dengan cara triangulasi (gabungan)". Penulis menggunakan metode fenomenologi, karena Penulis beranggapan bahwa penggunaan metode ini memungkinkan Penulis untuk pengamatan secara mendalam mengenai promosi cyber Film Bumi Manusia. Teknik analisis data penelitian ini menggunakan reduksi data, penyajian data, dan menarik 
kesimpulan. Untuk menguji keabsahan data Penulis menggunakan teknik triangulasi (Nasution, 2003) yaitu wawancara, observasi, dan dokumen.

Dalam penelitian ini Penulis mewawancarai 7 orang narasumber sebagai informan penelitian, dengan 1 narasumber utama dan 1 narasumber pendukung, serta 5 narasumber umum. Narasumber utama yaitu Frederica yang merupakan Produser Film Bumi Manusia dari Falcon Pictures. Narasumber pendukung adalah Hans De Kraker yang merupakan aktor dalam Film Bumi Manusia yang turut melakukan kegiatan promosi Film Bumi Manusia. Sedangkan narasumber umum adalah masyarakat yang dipilih secara acak, dan telah menonton Film Bumi Manusia, berusia 18 tahun, berdomisili di Jakarta, serta bersedia diwawancara dan dianggap mampu memberikan pandangan kritis baik terhadap produksi film maupun kegiatan promosi yang dilakukan oleh pihak Falcon Pictures untuk menarik minat menonton khalayak.

\section{Hasil Temuan dan Diskusi}

Bumi Manusia merupakan film drama biografi sejarah Indonesia Tahun 2019 yang disutradarai Hanung Bramantyo dan ditulis Salman Aristo. Film ini dialihwahanakan dari novel berjudul sama karya Pramoedya Ananta Toer. Film ini dibintangi Iqbaal Ramadhan, Mawar Eva de Jongh, dan Sha Ine Febriyanti. Film Bumi Manusia menceritakan kegamangan Minke antara kemajuan Eropa dan perjuangan membela tanah airnya serta hubungannya dengan Annelies. Berdasarkan hasil observasi lapangan yang dilakukan oleh Penulis pada saat melakukan penelitian di Kantor Rumah Produksi Falcon Pictures, Penulis mengetahui bahwa proses produksi Bumi Manusia bermula ketika Falcon Pictures mendapatkan hak alih wahana novel Bumi Manusia dan Perburuan pada 2014.

Bumi Manusia ditayangkan pada 15 Agustus 2019 bersamaan dengan Perburuan, setelah penayangan perdana pada 9 Agustus 2019 di Surabaya, Jawa Timur. Film ini sempat menguasai perolehan jumlah penonton terbanyak selama dua minggu berturut-turut sebelum digantikan Gundala. Film ini menjaring 1.316.583 penonton dengan perkiraan pendapatan kotor sekitar Rp52,7 miliar. Film ini mendapatkan sambutan positif dari kalangan pejabat politik dan masyarakat serta ulasan beragam dari kalangan pengulas film. Film ini dinominasikan di dua belas kategori Festival Film Indonesia 2019. Direncanakan film Bumi Manusia akan menjadi film pertama dari trilogy novel karya Pramoedya Ananta Toer. Film ini ditayangkan secara perdana bersamaan dengan Perburuan pada 9 Agustus di Surabaya Town Square, Surabaya, Jawa Timur. Frederica menuturkan pemilihan Kota Surabaya sebagai tempat penyelenggaraan kedua film ini disebabkan karena dianggap sesuai dengan tema kedua film yang latar belakang cerita tentang sejarah perjuangan Indonesia yang lekat dengan pertempuran pada 10 November 1945 di Surabaya.

Berdasarkan informasi yang diperoleh Penulis saat melakukan observasi di lapangan, diketahui sehari sebelum ditayangkan di seluruh Indonesia, Bumi Manusia mendapatkan penghargaan Award of Excellence dari Sinematek Indonesia; Sinematek menilai film ini memiliki keunggulan untuk diarsipkan, karena bermuatan nilai-nilai sejarah, budaya, kearifan lokal, dan juga memiliki kaidah sinematografi 
yang memadai. Film ini juga menjadi satu dari empat calon film yang mewakili Indonesia dalam Academy Awards ke-92 tahun 2020 selain Kucumbu Tubuh Indahku, Ave Maryam, dan 27 Steps of May.

Dari hasil wawancara yang dilakukan oleh Penulis terhadap para informan, maka didapatkan hasil penelitian mengenai Promosi Cyber Film Bumi Manusia. Adapun informan selaku narasumber utama dalam penelitian ini merupakan para pihak yang bertanggung jawab untuk melakukan kegiatan promosi film bumi manusia, dan masyarakat umum yang telah menonton film bumi manusia. Guna memperoleh informasi mendalam terkait promosi dan pemasaran film Bumi Manusia, Penulis melakukan wawancara dengan narasumber utama yakni Produser Film Bumi Manusia yaitu Ibu Frederica dari pihak Falcon Pictures yang merupakan perusahaan pemasaran film Bumi Manusia. Selain itu sebagai pihak yang melakukan kegiatan promosi, Penulis juga mewawancarai salah satu aktor yang memerankan tokoh dalam film bumi manusia, yaitu Bapak Hans De Kraker. Dalam penelitian ini Penulis juga turut mewawancarai 5 (lima) orang dari unsur masyarakat yang dipilih secara acak dengan kriteria telah menonton Film Bumi Manusia. Hal tersebut dilakukan Penulis dengan tujuan mengetahui bagaimana pengaruh promosi cyber film bumi manusia dalam menarik minat penonton penulis melakukan wawancara dengan penonton film Bumi Manusia.

Tabel 1. Profil Narasumber Utama

\begin{tabular}{|c|c|c|}
\hline asumber & Nama & Keterangan \\
\hline $\begin{array}{c}1 \\
\text { asumber } \\
\text { utama) }\end{array}$ & Frederica & $\begin{array}{l}\text { er Falcon Pictures yang turut membesarkan nama Rumah } \\
\text { Produksi tersebut, Produser wanita yang namanya besar } \\
\text { karena karya-karya yang dihasilkan turut gemilang. } \\
\text { Frederica sosok produser muda yang memiliki tinggi rata- } \\
\text { rata wanita Indonesia pada umumnya, ia mempunyai sikap } \\
\text { ramah terhadap orang yang dikenalnya. Jika berbicara } \\
\text { sangat tegas dan jelas menggunakan campuran bahasa } \\
\text { Inggris dan Indonesia, menggambarkan dirinya sebagai } \\
\text { seorang yang berwawasan luas di bidangnya dan modern. }\end{array}$ \\
\hline $\begin{array}{c}2 \\
\text { isumber) }\end{array}$ & Hans De Kraker & $\begin{array}{l}\text { Laki-laki yang bertubuh jangkung, dan berkumis layaknya } \\
\text { kapten kapal pada film kartun ini merupakan brand } \\
\text { ambassador dari minuman beralkohol. Aktor berkebangsaan } \\
\text { Belanda ini lahir pada } 23 \text { Desember } 1967 \text {. } \\
\text { Hans merupakan seorang yang bekerja di bidang IT dan } \\
\text { memiliki ketertarikan yang besar terhadap dunia seni Peran. } \\
\text { Ia kemudian memutuskan untuk memulai karirnya di } \\
\text { perfilman sejak tahun } 2015 \text {, dan hingga saat ini Hans telah } \\
\text { membintangi sebanyak } 30 \text { film layar lebar. } 6 \text { fim } \\
\text { diantaranya adalah film sejarah. Dalam Film Bumi Manusia, } \\
\text { Hans berperan sebagai sahabat Minke yang merupakan eks } \\
\text { tentara Belanda yang jatuh cinta dengan seorang gadis } \\
\text { pribumi. Sebagai aktor di film ini Hans turut melakukan } \\
\text { promosi Film Bumi Manusia, sebagaimana dilakukan juga } \\
\text { oleh para aktor lainnya yang berperan di Film Bumi } \\
\text { Manusia. }\end{array}$ \\
\hline
\end{tabular}


Tabel 2. Profil Narasumber Umum

\begin{tabular}{|c|c|c|}
\hline Narasumber & Nama & Keterangan \\
\hline 1 & Fakhira Maryam Putri Adhyaksa & $\begin{array}{l}19 \text { tahun seorang mahasiswa Ilmu } \\
\text { Komunikasi di FISIP semester 3, Lahir } \\
\text { di Jakarta 28 Maret 2000, yang } \\
\text { mengetahui promosi yang dilakukan film } \\
\text { Bumi Manusia dan telah menonton Film } \\
\text { Bumi Manusia; }\end{array}$ \\
\hline 2 & Desi Melinda & $\begin{array}{l}\text { Berusia } 20 \text { tahun, lahir di Jakarta } 28 \\
\text { Agustus } 1999 \text {, seorang mahasiswa } \\
\text { jurusan kesejahteraan sosial di } \\
\text { Universitas Islam Negeri Jakarta, yang } \\
\text { mengetahui promosi film Bumi Manusia } \\
\text { melalui media sosial yang telah } \\
\text { menonton film Bumi Manusia }\end{array}$ \\
\hline 3 & Agung & $\begin{array}{l}\text { Berusia } 23 \text { tahun seorang mahasiswa S1 } \\
\text { yang mengetahui promosi yang } \\
\text { dilakukan film Bumi Manusia dan telah } \\
\text { menonton Film Bumi Manusia; }\end{array}$ \\
\hline 4 & $\begin{array}{c}\text { Marwah } \\
\text { Fitrasari Putri }\end{array}$ & $\begin{array}{l}\text { Berusia } 28 \text { tahun, lahir di Palu } 11 \text { Juni } \\
\text { 1991, bekerja di Kementerian Dalam } \\
\text { Negeri Ditjen Bina Pemerintahan Desa } \\
\text { yang mengetahui promosi film Bumi } \\
\text { Manusia melalui media sosial yang telah } \\
\text { menonton film Bumi Manusia; }\end{array}$ \\
\hline 5 & Steven & $\begin{array}{l}\text { Berusia } 26 \text { tahun seorang pegawai } \\
\text { swasta yang mengetahui promosi film } \\
\text { Bumi Manusia melalui media sosial } \\
\text { yang telah menonton film Bumi } \\
\text { Manusia. }\end{array}$ \\
\hline
\end{tabular}

(Sumber: Data Peneliti, 2019)

\section{Komunikasi Periklanan Film Bumi Manusia}

Berdasarkan hasil wawancara Penulis dengan narasumber selaku informan, diketahui bahwa dalam promosi cyber Film Bumi Manusia, melakukan komunikasi periklanan dengan tujuan untuk memberikan pesan kepada masyarakat mengenai peluncuran film Bumi Manusia. Dalam promosi Film, dimuat teaser dan kalimat sinopsis yang terkait dengan trending topic, dengan tujuan memberikan stimulus tersendiri untuk khalayak sebagai calon penonton, agar menimbulkan rasa keingintahuan dan mencoba menebak-nebak apa yang menjadi akhir cerita Film Bumi Manusia sehingga khalayak berkeinginan menonton Film tersebut. Berdasarkan hasil wawancara Penulis dengan Narasumber diketahui bahwa informasi yang diberikan persis seperti hasil observasi Penulis. Dari hasil data di lapangan, Penulis mengetahui bahwa besaran dana yang dikeluarkan untuk promosi Film Bumi Manusia hampir mencapai angka 15 miliar Rupiah, dengan menggunakan sarana promosi di media sosial hingga di stasiun TV dan media cetak. Hasil wawancara dan observasi tersebut ketika Penulis sandingkan dengan teori Promotional mix yang digunakan sebagai pisau analisis membentuk asumsi Penulis 
bahwa komunikasi periklanan Film Bumi Manusia menggunakan instrumen dasar bauran promosi yang digunakan untuk mencapai tujuan komunikasi perusahaan sebagaimana yang dikemukakan oleh George Belch dan Michael Belch.

\section{Media Sosial atau Media Online Sebagai Teknologi Komunikasi}

Adapun komunikasi periklanan yang dilakukan oleh Film Bumi Manusia adalah melalui media sosial dilakukan oleh pihak Film Bumi Manusia memang salah satunya adalah untuk menghemat biaya promosi. Dari hasil data di lapangan, Penulis mengetahui jelas bahwa salah satu media sosial yang digunakan untuk promosi cyber ialah Instagram. Promosi dengan menggunakan media sosial Instagram dipilih karena pertimbangan pada saat ini banyak generasi muda yang beralih ke Instagram dibandingkan media sosial lainnya. Selain itu, penulis menemukan fakta bahwa dalam kategori new media, penggunaan media sosial yang didukung teknologi komunikasi dan digunakan untuk promosi Film Bumi Manusia antara lain berbentuk: forum internet, weblog, media social, microblogging, wiki, podcast, foto atau gambar, video, dan surat kabar elektronik, serta perangkat lain dalam penggunaan informasi, meskipun demikian Penulis menyimpulkan penggunaan Instagram dan Twitter merupakan pilihan dominan untuk melakukan promosi Film Bumi Manusia.

Hasil wawancara dan observasi tersebut ketika Penulis sandingkan dengan teori Promotional mix yang digunakan sebagai pisau analisis membentuk asumsi Penulis bahwa komunikasi periklanan Film Bumi Manusia menggunakan instrumen dasar bauran promosi, dengan dominan bauran promosi adalah internet marketing yang digunakan untuk mencapai tujuan komunikasi perusahaan sebagaimana yang dikemukakan oleh George Belch dan Michael Belch.

\section{Promosi Cyber Film Bumi Manusia}

Berikut ini Penulis sajikan data tabel hasil wawancara penulis dengan narasumber selaku informan dalam penelitian ini, yang telah diuji keabsahan oleh Penulis dengan observasi lapangan di kantor rumah produksi Falcon Pictures:

Tabel 3. Analisis Promosi Cyber Film Bumi Manusia Berdasarkan Wawancara Narasumber dan Observasi Lapangan Penulis

\begin{tabular}{|c|l|c|c|c|c|c|c|}
\hline No & Narasumbe & \multicolumn{6}{|c|}{ Promotional Mix } \\
\cline { 3 - 8 } & \multicolumn{1}{r}{} & $\begin{array}{c}\text { Ikla } \\
\mathbf{n}\end{array}$ & $\begin{array}{c}\text { Direct } \\
\text { marketin } \\
\text { g }\end{array}$ & $\begin{array}{c}\text { Persona } \\
\text { l selling }\end{array}$ & $\begin{array}{c}\text { Publika } \\
\text { si }\end{array}$ & $\begin{array}{c}\text { Internet } \\
\text { marketin } \\
\text { g }\end{array}$ & $\begin{array}{c}\text { Promosi } \\
\text { penjuala } \\
\text { n }\end{array}$ \\
\hline 1 & Frederica & $\mathbf{v}$ & $\mathbf{v}$ & - & $\mathbf{v}$ & $\mathbf{v}$ & $\mathbf{v}$ \\
\hline $\mathbf{2}$ & Hans DK & $\mathbf{v}$ & $\mathbf{v}$ & - & $\mathbf{v}$ & $\mathbf{v}$ & $\mathbf{v}$ \\
\hline $\mathbf{3}$ & $\begin{array}{l}\text { Marwah } \\
\text { FP }\end{array}$ & $\mathbf{v}$ & - & - & $\mathbf{v}$ & $\mathbf{v}$ & $\mathbf{v}$ \\
\hline $\mathbf{4}$ & Fakhira & $\mathbf{v}$ & - & - & $\mathbf{v}$ & $\mathbf{v}$ & $\mathbf{v}$ \\
\hline $\mathbf{5}$ & Desi & $\mathbf{v}$ & - & - & $\mathbf{v}$ & $\mathbf{v}$ & $\mathbf{v}$ \\
\hline $\mathbf{6}$ & Agung & $\mathbf{v}$ & - & - & $\mathbf{v}$ & $\mathbf{v}$ & $\mathbf{v}$ \\
\hline $\mathbf{7}$ & Kevin & $\mathbf{v}$ & - & - & $\mathbf{v}$ & $\mathbf{v}$ & $\mathbf{v}$ \\
\hline
\end{tabular}

Sumber: Data Peneliti (2019) 
Secara keseluruhan dengan melihat Tabel 3 diatas dapat dijelaskan promosi yang dilakukan oleh Film Bumi Manusia, bahwa sebagai pihak yang bertanggung jawab untuk melakukan kegiatan promosi Film Bumi Manusia, diketahui Falcon Pictures memilih untuk melakukan direct marketing dengan mengadakan gala premiere di Kota Surabaya, dan narasumber umum tidak mendapatkan proses direct marketing disebabkan para narasumber adalah masyarakat yang berdomisili di Kota Jakarta. Narasumber Utama dan Narasumber Pendukung tidak menggunakan personal selling dalam melakukan promosi film, dan hal tersebut juga tidak ditemukan pada narasumber umum selaku masyarakat yang menonton Film Bumi Manusia.

\section{Simpulan}

Berdasarkan hasil penelitian yang telah dilakukan oleh Penulis maka dapat disimpulkan sebagai berikut :

1. Komunikasi periklanan yang digunakan oleh Film Bumi Manusia menggunakan komunikasi periklanan melalui media massa baik media cetak atau online.

2. Film Bumi Manusia menggunakan media sosial khususnya Instagram sebagai teknologi komunikasi promosi cyber.

3. Promosi cyber yang dilakukan untuk Film Bumi Manusia menggunakan elemen dasar bauran promosi yakni, iklan, internet marketing, promosi penjualan, publikasi dan pemasaran langsung, dan tidak menggunakan personal selling.

berikut:

Dari kesimpulan penelitian diatas, maka Penulis memberikan saran sebagai

1. Mengingat promosi yang dilakukan difokuskan pada media sosial Instagram, maka disarankan dapat menggunakan media sosial lainnya selain menggunakan Instagram, mengingat banyak media sosial lainnya yang digunakan oleh anak muda, seperti Snapgram;

2. Mengingat peluncuran film perdana dilakukan hanya di Kota Surabaya, maka disarankan untuk melakukan peluncuran film pada beberapa kota secara serentak, sehingga dapat mencapai masyarakat secara luas;

3. Memperluas segmentasi penonton, bukan hanya untuk milenial tetapi juga untuk segmentasi dewasa pekerja atau orang tua sehingga dapat menarik penonton lebih banyak lagi. Mengingat film ini adalah adaptasi dari novel yang kontroversi di zaman orde baru.

\section{Ucapan Terima Kasih}

Penulis ingin menyampaikan rasa terima kasih kepada semua pihak yang ikut terlibat dan telah membantu Penulis selama proses penelitian ini berlangsung, yaitu:

1. Kepada Tuhan YME, atas berkat dan rahmat-Nya yang menyertai Penulis selama proses penyusunan skripsi ini;

2. Kepada Dr. Riris Loisa, M.Si; Yugih Setyanto, S.Sos., M.Si., Sinta Paramita, SIP., MA; Bapak Dr. Eko Harry Susanto, M.Si.; Ibu Frederica; Bapak Hans De-Kraker; Marwah Fitrasari Putri; James Engelen; Ketua Ombudsman Prof. Amzulian Rifai; Marwa, Kpia, Ilyas; Dosen-dosen 
pengajar Fakultas Komunikasi Untar; Bapak dan ibu tim pendukung administrasi Fakultas Komunikasi; Christoforus Richard Massa; dan untuk teman-teman saya yang luar biasa selama mengikuti pendidikan di Untar.

\section{Daftar Pustaka}

Nasution. (2003). Metode Penelitian Naturalistik Kualitatif. Bandung: Tarsito.

Sugiyono, 2011. Metode Penelitian Kuantitatif dan Kualitatif dan R \& D. Bandung: CV Alfabeta.

Susanto, Eko Harry. 2018. Komunikasi Manusia; Teori dan Praktik Dalam Penyampaian Gagasan. Jakarta: Mitra Wacana Media.

http://filmindonesia.or.id/viewer\#.XXde1CUxWEc, diakses pada Hari Senin Tanggal 10 September 2019, Waktu 15.43 WIB).

http://www.google.co.id/amp/s/entertainment.uzone.id/amp/-falcon-habiskan-rp50miliar-produksi-film-bumi-manusia, diunggah pada 5 Agustus 2019 dan diakses pada Hari Senin Tanggal 10 September 2019 Pukul 16.17 WIB) 